\title{
2019 novel coronavirus outbreak: a quiz or final exam?
}

\author{
Jiuyang $\mathrm{Xu}^{1}$, Yijun $\mathrm{Chen}^{1}$, Hao $\mathrm{Chen}^{1}$, Bin Cao $(\bowtie)^{2,3,4}$ \\ ${ }^{1}$ Tsinghua University School of Medicine, Beijing 100084, China; ${ }^{2}$ Department of Pulmonary and Critical Care Medicine, Center for \\ Respiratory Medicine, China-Japan Friendship Hospital, Beijing 100029, China; ${ }^{3}$ Institute of Respiratory Medicine, Chinese Academy of \\ Medical Sciences, Peking Union Medical College, Beijing 100005, China; ${ }^{4}$ Tsinghua University-Peking University Joint Center for Life \\ Sciences, Beijing 100084, China
}

(C) Higher Education Press and Springer-Verlag GmbH Germany, part of Springer Nature 2020

\begin{abstract}
The 2019 novel coronavirus (2019-nCoV) is an emerging pathogen and is threatening the global health. Strikingly, more than 28000 cases and 550 deaths have been reported within two months from disease emergence. Armed with experience from previous epidemics in the last two decades, clinicians, scientists, officials, and citizens in China are all contributing to the prevention of further 2019-nCoV transmission. Efficient preliminary work has enabled us to understand the basic characteristics of 2019-nCoV, but there are still many unanswered questions. It is too early now to judge our performance in this outbreak. Continuous and strengthened efforts should be made not only during the epidemic, but also afterwards in order to prepare for any incoming challenges.
\end{abstract}

Keywords 2019-nCoV; novel coronavirus; epidemic; public response

\section{Introduction}

The 2019 novel coronavirus (2019-nCoV) outbreak is currently bringing challenges to China and the whole world. First reported in December 2019, it has caused over 28000 cases in around 2 months, among whom at least 3800 have severe illness and more than 550 deaths have been reported (data as of February 5, 2020) [1]. On January 30, World Health Organization has announced it as a Public Health Emergency of International Concern [2]. Since direct human transmission and asymptomatic infection have been revealed for 2019-nCoV [3], health authorities in China are facing an enormous challenge on disease management and control.

$2019-\mathrm{nCoV}$ is the third highly pathogenic coronavirus emerging in the 21st century, also one of the epidemics or pandemics since the millennium (Fig. 1). Human coronavirus had been overlooked for a long time before the severe acute respiratory syndrome coronavirus (SARS-CoV) outbreak in 2002, leaving 8096 infections with a mortality rate of nearly $10 \%$ [4]. Fortunately, public health measures, including isolation and quarantine, finally put an end to the SARS pandemic in summer 2003. In 2009, the influenza A/H1N1 swept over 200 countries and regions, leaving

Received February 5, 2020; accepted February 6, 2020

Correspondence: Bin Cao, caobin_ben@163.com with more than 18449 deaths [5]. Subsequently, Middle East respiratory syndrome coronavirus (MERS-CoV), another coronavirus, has posed a continuous threat to global health since 2012. Considered as a zoonotic virus, MERS-CoV infection is reported occasionally and sometimes in cluster, such as the outbreak in South Korea where one infected traveler back from the Middle East led to 186 infections and 36 deaths in 2015 [6]. By November 2019, MERS-CoV has infected 2494 individuals and caused 858 deaths [7]. In addition, Ebola virus outbreak in 2014 and Zika virus outbreak in 2015 both contributed dramatic damage to the affected countries.

\section{Public responses to 2019-nCoV outbreak and previous experience}

Experience from previous epidemics has trained us to perform more positively in the incoming threat. For example, the disastrous outbreak of SARS in 2003 promoted the reformation of Chinese Center for Disease Control and Prevention (CCDC), driving the establishment of a better disease surveillance network. As a result, relatively quick response and actions were made during the MERS outbreak in South Korea in 2015, avoiding further spread in China. Realizing the severity of SARS-CoV as a respiratory virus, the detection of pneumonia of unknown origin in 2019-nCoV outbreak enabled relatively early 


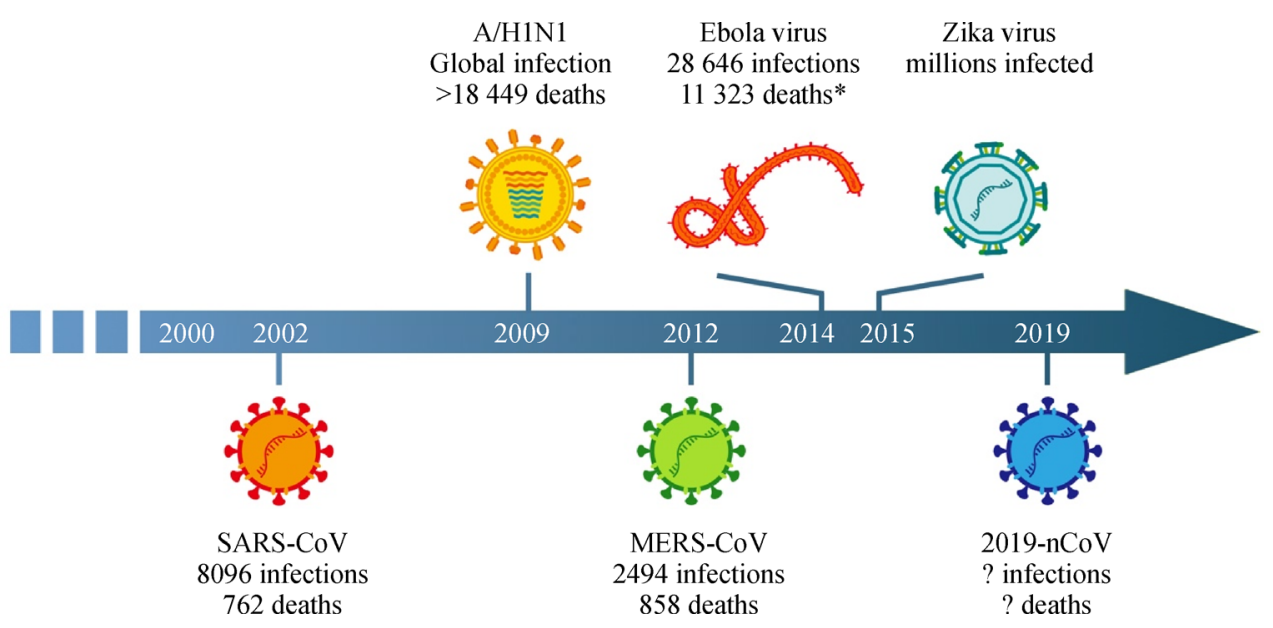

Fig. 1 Major epidemics and pandemics in the 21st century. Case numbers and fatality are retrieved from the World Health Organization website. *only data from the 2014-2016 epidemic for Ebola virus is shown.

alarm from health authorities and raised awareness for medical staff to equip personal protection methods when dealing with suspected cases. However, material reserve (i.e., gloves, protective suits) for health worker is far from enough with the outbreak evolving, indicating the insufficiency of financial support and emergency practice.

The rapid progress in science nowadays has also prepared us for the recent 2019-nCoV outbreak. First, modern biological techniques developed in the last decade have greatly promoted the speed of pathogen detection. The whole-genome sequencing and isolation of 2019nCoV strains were accomplished in early January 2020, within two weeks from identifying the outbreak. In 2003, the same process took 4 months [8]. Second, the more advanced hospital facilities in China, including advanced life support devices (i.e., extracorporeal membrane oxygenation), have improved our ability to manage severe cases, although the equipment is still in shortage in the central disease area.

The outbreaks of SARS and MERS informed us about the possibility of highly pathogenic coronavirus, but there are still many unanswered questions. Although basic research has generated several promising candidates [9, $10]$, we are still not armed with vaccines or specific antiviral drugs against coronaviruses 17 years after SARS and 7 years after MERS outbreak. The novel coronavirus indeed hit this weakness. As of January 31, the number of confirmed cases for 2019-nCoV has surpassed that of SARS-CoV and the number is still climbing.

Besides lack of specific antiviral treatments and deficiency in the understanding of novel virus, many other factors have also contributed to the wider transmission of 2019-nCoV, such as increased population density coming with the increased urbanization, easier longdistance travel resulting from improved public transportation, as well as the surge of travelers during the Spring
Festival travel rush. While the more convenient lifestyle enhances the transmission of 2019-nCoV, it also facilitates personal prevention after the outbreak. For example, the more advanced personal terminal equipment such as smartphones facilitates information sharing and real-time epidemic update for disease control. In addition, onlineordered service including take-out food, online shopping, and fresh product delivery make self-isolation in urban areas relatively possible.

We are glad to see that multiple public health measures were taken to prevent the disease transmission. 2019$\mathrm{nCoV}$ was identified as Category B infectious disease and managed as Class A on January 20 according to the Law of the People's Republic of China on Prevention and Treatment of Infectious Diseases. On January 23, Wuhan City took the lead to suspend all public transport to prevent further transmission during the Spring Festival holiday (starting from January 25), which was then simulated by several other neighboring cities. At the same time, Chinese community-based governments also adapt receptive measures to propagate the threat brought by $2019-\mathrm{nCoV}$ and recommend personal hygiene in the communities. With the popularity of smartphones, these propagations arrive at almost every family to partially slow down the spread of the disease. As of February 3, a total of 47.0 billion RMB has been applied to disease control and prevention [11].

\section{Preliminary findings in clinical and scientific features of 2019-nCoV}

The authorities as well as the scientific community in China have been working diligently to battle against the outbreak. After the local authority was informed of the cluster of pneumonia of unknown origin associated with 
Huanan Seafood Market on December 31, 2019, an expert team of clinicians, epidemiologists, scientists, and officials was dispatched to Wuhan, and suspected cases were soon transferred to a designated hospital (Jinyintan Hospital). Several groups have independently isolated a novel pathogen from the lower respiratory tract of the patients in early January 2020. Zhu et al. identified the pathogen as a novel coronavirus (2019-nCoV) by unbiased sequencing and obtained the transmission electron microscopy image [12]. This finding was supported by data from other groups and genomic studies showed that $2019-\mathrm{nCoV}$ was closest to a SARS-like coronavirus in bats, and that the receptorbinding domain (RBD) was close to that of SARS-CoV, suggesting ACE2 as the possible receptor [13-16]. However, more studies are needed to fulfill Koch's postulate for 2019-nCoV and identify its cellular receptor. Hunting for the animal source of $2019-\mathrm{nCoV}$ is also under way.

Apart from the basic science findings, clinicians have worked efficiently to provide first-hand experience with 2019-nCoV patients. Chan et al. reported a case of a family cluster of 2019-nCoV infection, five of whom had travel history to Wuhan but one did not, providing the first evidence that 2019-nCoV was able to transmit from person-to-person [3]. An epidemiology study conducted by Li et al. also confirmed cluster cases indicating early human transmission [17]. Huang et al. gathered clinical features of the first cohort of 41 laboratory-confirmed cases and found that fever, dry cough, and dyspnea were common symptoms for the new disease [18]. Chen et al. extended the description by gathering another 99 cases and adding details on combined bacterial and fungal coinfections [19]. Experience from the front line helped to form a national guideline for the management of the novel coronavirus induced pneumonia patients (now fifth edition) [20]. This is not the end of clinical research on 2019-nCoV. We are expecting good news from Chinese physicians and scientists.

\section{Conclusions}

In this era of We Media nowadays, there are more challenges than ever in preventing and controlling infectious diseases. On one hand, social media promotes rapid information flow, facilitating efficient information exchange and enabling timely decision-making. On the other hand, it also allows rumor, misunderstanding, and fear to quickly turn around in the vast population. It should be noted that the words spoken by specialists are easily spread in public, with a high possibility of misunderstanding the jargons and following irrational behaviors. Although the academic journal is still the best place for scientists to share and exchange viewpoints, it is not the only place, especially for civilians who do not have an academic background but are eager to know more. Popular science readings are equally important, or at least as a supplement to the academic articles, in sharing scientific knowledge. There will be less fear when armed with knowledge.

The 2019-nCoV outbreak is an examination for the whole world, and for everyone. At the current stage, it is still too early to judge our actions in this outbreak. We have accomplished many, and more efforts are needed to better understand the novel virus, with various questions on its source, animal reservoirs, transmission and evolution pattern, pathogenesis, as well as appropriate treatment.

2019-nCoV is only a quiz but not the final examination, with novel threats around the corner. Therefore, a continuous and strengthened emphasis should be put on potential pathogens, such as coronaviruses, that might infect humans and cause epidemic. Financial support, research work, and personal awareness of crisis are not supposed to wane with the departure of a sudden or "temporary" threat. We do need to be prepared, rather than be surprised.

\section{Compliance with ethics guidelines}

Jiuyang Xu, Yijun Chen, Hao Chen, and Bin Cao declare no conflicts of interest. This manuscript is a commentary and does not involve a research protocol requiring approval by the relevant institutional review board or ethics committee.

\section{References}

1. National Health Commission of China. The latest information for 2019 novel coronavirus infected pneumonia by Feb 5, 2020. 2020. http://www.nhc.gov.cn/xcs/yqfkdt/202002/6b1e029fd22c484281c bc5e73dae98fc.shtml (in Chinese) (accessed February 6, 2020)

2. World Health Organization. Statement on the second meeting of the International Health Regulations (2005) Emergency Committee regarding the outbreak of novel coronavirus (2019-nCoV). 2020. https://www.who.int/news-room/detail/30-01-2020-statement-onthe-second-meeting-of-the-international-health-regulations-(2005)emergency-committee-regarding-the-outbreak-of-novel-coronavirus-(2019-ncov) (accessed February 4, 2020)

3. Chan JF, Yuan S, Kok KH, To KK, Chu H, Yang J, Xing F, Liu J, Yip CC, Poon RW, Tsoi HW, Lo SK, Chan KH, Poon VK, Chan WM, Ip JD, Cai JP, Cheng VC, Chen H, Hui CK, Yuen KY. A familial cluster of pneumonia associated with the 2019 novel coronavirus indicating person-to-person transmission: a study of a family cluster. Lancet 2020 Jan 24. [Epub ahead of print] doi:10.1016/S0140-6736(20)30154-9

4. World Health Organization. Summary of probable SARS cases with onset of illness from 1 November 2002 to 31 July 2003. 2004. http:// www.who.int/csr/sars/country/table2004_04_21/en/ (accessed February 4,2020$)$

5. World Health Organization. Pandemic (H1N1) 2009—update 112. 
2010. https://www.who.int/csr/don/2010_08_06/en/ (accessed February 4,2020 )

6. World Health Organization. Middle East respiratory syndrome coronavirus (MERS-CoV) - Republic of Korea. 2015. https://www. who.int/csr/don/25-october-2015-mers-korea/en/ (accessed February 4, 2020)

7. World Health Organization. Middle East respiratory syndrome coronavirus (MERS-CoV). 2019. https://www.who.int/emergencies/mers-cov/en/ (accessed February 4, 2020)

8. Marra MA, Jones SJ, Astell CR, Holt RA, Brooks-Wilson A, Butterfield YS, Khattra J, Asano JK, Barber SA, Chan SY, Cloutier A, Coughlin SM, Freeman D, Girn N, Griffith OL, Leach SR, Mayo M, McDonald H, Montgomery SB, Pandoh PK, Petrescu AS, Robertson AG, Schein JE, Siddiqui A, Smailus DE, Stott JM, Yang GS, Plummer F, Andonov A, Artsob H, Bastien N, Bernard K, Booth TF, Bowness D, Czub M, Drebot M, Fernando L, Flick R, Garbutt M, Gray M, Grolla A, Jones S, Feldmann H, Meyers A, Kabani A, Li Y, Normand S, Stroher U, Tipples GA, Tyler S, Vogrig R, Ward D, Watson B, Brunham RC, Krajden M, Petric M, Skowronski DM, Upton C, Roper RL. The genome sequence of the SARS-associated coronavirus. Science 2003; 300(5624): 1399 1404

9. Zumla A, Chan JF, Azhar EI, Hui DS, Yuen KY. Coronaviruses-drug discovery and therapeutic options. Nat Rev Drug Discov 2016; 15(5): $327-347$

10. Xu J, Jia W, Wang P, Zhang S, Shi X, Wang X, Zhang L. Antibodies and vaccines against Middle East respiratory syndrome coronavirus. Emerg Microbes Infect 2019; 8(1): 841-856

11. Ministry of Finance of the People's Republic of China. The government at all levels continued to increase input and allocated a total of 47 billion yuan for epidemic prevention and control. 2020. http://sbs.mof.gov.cn/gongzuodongtai/202002/t20200203_3465390. htm (in Chinese) (accessed February 4, 2020)

12. Zhu N, Zhang D, Wang W, Li X, Yang B, Song J, Zhao X, Huang B, Shi W, Lu R, Niu P, Zhan F, Ma X, Wang D, Xu W, Wu G, Gao GF, Tan W; China Novel Coronavirus Investigating and Research Team. A novel coronavirus from patients with pneumonia in China, 2019. N Engl J Med 2020 Jan 24. [Epub ahead of print] doi: 10.1056/ NEJMoa2001017

13. Chan JF, Kok KH, Zhu Z, Chu H, To KK, Yuan S, Yuen KY. Genomic characterization of the 2019 novel human-pathogenic coronavirus isolated from a patient with atypical pneumonia after visiting Wuhan. Emerg Microbes Infect 2020; 9(1): 221-236

14. Ren L, Wang Y, Wu Z, Xiang Z, Guo L, Xu T,Jiang Y, Xiong Y, Li Y, Li H, Fan G, Gu X, Xiao Y, Gao H, Xu J, Yang F, Wang X, Wu
C, Chen L, Liu Y, Liu B, Yang J, Wang X, Dong J, Li L, Huang C, Zhao J, Hu Y, Cheng Z, Liu L, Qian Z, Qin C, Jin Q, Cao B, Wang J. Identification of a novel bat-origin coronavirus causing severe pneumonia in human: a descriptive study. Chin Med J 2020. [Epub ahead of print] doi: 10.3760/cma.j.issn.0366-6999.2020.00.E001

15. Lu R, Zhao X, Li J, Niu P, Yang B, Wu H, Wang W, Song H, Huang B, Zhu N, Bi Y, Ma X, Zhan F, Wang L, Hu T, Zhou H, Hu Z, Zhou W, Zhao L, Chen J, Meng Y, Wang J, Lin Y, Yuan J, Xie Z, Ma J, Liu W J, Wang D, Xu W, Holmes EC, Gao GF, Wu G, Chen W, Shi W, Tan W. Genomic characterisation and epidemiology of 2019 novel coronavirus: implications for virus origins and receptor binding. Lancet 2020 Jan 30. [Epub ahead of print] doi: 10.1016/ S0140-6736(20)30251-8

16. Zhou P, Yang XL, Wang XG, Hu B, Zhang L, Zhang W, Si HR, Zhu Y, Li B, Huang CL, Chen HD, Chen J, Luo Y, Guo H, Jiang RD, Liu MQ, Chen Y, Shen XR, Wang X, Zheng XS, Zhao K, Chen QJ, Deng F, Liu LL, Yan B, Zhan FX, Wang YY, Xiao GF, Shi ZL. A pneumonia outbreak associated with a new coronavirus of probable bat origin. Nature $2020 \mathrm{Feb} 3$. [Epub ahead of print] doi: 10.1038/ s41586-020-2012-7

17. Li Q, Guan X, Wu P, Wang X, Zhou L, Tong Y, Ren R, Leung KSM, Lau EHY, Wong JY, Xing X, Xiang N, Wu Y, Li C, Chen Q, Li D, Liu T, Zhao J, Li M, Tu W, Chen C, Jin L, Yang R, Wang Q, Zhou S, Wang R, Liu H, Luo Y, Liu Y, Shao G, Li H, Tao Z, Yang Y, Deng Z, Liu B, Ma Z, Zhang Y, Shi G, Lam TTY, Wu JTK, Gao GF, Cowling BJ, Yang B, Leung GM, Feng Z. Early transmission dynamics in Wuhan, China, of novel coronavirus-infected pneumonia. N Engl J Med 2020 Jan 29. [Epub ahead of print] doi: 10.1056/ NEJMoa2001316

18. Huang C, Wang Y, Li X, Ren L, Zhao J, Hu Y, Zhang L, Fan G, Xu J, Gu X, Cheng Z, Yu T, Xia J, Wei Y, Wu W, Xie X, Yin W, Li H, Liu M, Xiao Y, Gao H, Guo L, Xie J, Wang G, Jiang R, Gao Z, Jin Q, Wang J, Cao B. Clinical features of patients infected with 2019 novel coronavirus in Wuhan, China. Lancet 2020 Jan 24. [Epub ahead of print] doi: 10.1016/S0140-6736(20)30183-5

19. Chen N, Zhou M, Dong X, Qu J, Gong F, Han Y, Qiu Y, Wang J, Liu Y, Wei Y, Xia J, Yu T, Zhang X, Zhang L. Epidemiological and clinical characteristics of 99 cases of 2019 novel coronavirus pneumonia in Wuhan, China: a descriptive study. Lancet 2020 Jan 30. [Epub ahead of print] doi: 10.1016/S0140-6736(20)30211-7

20. National Health Commission of China. The issuance of the diagnosis and treatment programme for pneumonia of novel coronavirus infections (pilot fifth edition). 2020. http://www.nhc. gov.cn/yzygj/s7653p/202002/3b09b894ac9b4204a79db5b8912d4 440.shtml (in Chinese) (accessed February 5, 2020) 